\author{
J-ABDIPAMAS (Jurnal Pengabdian Kepada Masyarakat) \\ Vol. $3 \bullet$ No. $2 \bullet 2019$ \\ ISSN : 2581-1320 (Print) ISSN : 2581-2572 (Online) \\ Homepage: http://ejurnal.ikippgribojonegoro.ac.id/index.php/J-ABDIPAMAS
}

\title{
PELATIHAN PENELITIAN TINDAKAN KELAS BAGI GURU MTS MIZANUL 'ULUM DESA SANROBONE KABUPATEN TAKALAR
}

\author{
Umar Mansyur ${ }^{1}$, Rahmat $^{2}$ \\ ${ }^{1}$ Universitas Muslim Indonesia. Email: umar.mansyur@umi.ac.id \\ 2Universitas Muslim Indonesia. Email: rahmat.sastra@umi.ac.id
}

\begin{abstract}
Being a professional teachers is required a number of requirements, such as having an adequate professional education qualification and actively developing themselves through classroom action research activities. Meanwhile, Classroom Action Research activities by most teachers are considered as something difficult and confusing, including for teachers at MTs Mizanul 'Ulum Sanrobone Takalar District who are community service partners. For this reason, as a solution to these problems, Classroom Action Research Training is conducted. The method used in this activity is the training method. Participants who were targeted partners were 25 teachers. In its implementation, the training takes place in three stages, namely preparation, implementation, and evaluation. The results of this training activity were carried out well and smoothly. The training carried out also produced a Classroom Action Research Guidelines that could be used teachers as a guide in preparing Classroom Action Research. In addition, the training received a positive response from the teachers. This is evidenced from the results of the training evaluation questionnaire analysis which showed that as many as $64 \%$ of participants gave a very useful category response. Thus, this Classroom Action Research Training can improve the motivation, knowledge and skills of MTs Mizanul 'Ulum Sanrobone teachers in Takalar District in conducting Classroom Action Research.
\end{abstract}

Keywords: Classroom Action Research, Teacher

\begin{abstract}
ABSTRAK
Menjadi guru yang profesional dituntut dengan sejumlah persyaratan, seperti memiliki kualifikasi pendidikan profesi yang memadai dan aktif melakukan pengembangan diri melalui kegiatan penelitian tindakan kelas. Sementara, kegiatan Penelitian Tindakan Kelas oleh sebagian besar guru dianggap sebagai sesuatu yang sulit dan membingungkan, termasuk bagi guru-guru di MTs Mizanul 'Ulum Sanrobone Kabupaten Takalar yang menjadi mitra pengabdian masyarakat ini. Untuk itu, sebagai solusi atas permasalahan tersebut, dilakukan Pelatihan Penelitian Tindakan Kelas. Metode yang digunakan dalam kegiatan ini adalah metode pelatihan. Peserta yang menjadi mitra sasar sebanyak 25 guru. Dalam pelaksanaannya, pelatihan berlangsung dalam tiga tahapan, yakni persiapan, pelaksanaan, dan evaluasi. Hasil kegiatan pelatihan ini terlaksana dengan baik dan lancar. Pelatihan yang dilaksanakan juga menghasilkan Pedoman Penelitian Tindakan Kelas yang dapat dijadikan para guru sebagai panduan dalam menyusun Penelitian Tindakan Kelas. Selain itu, pelaksanaan pelatihan mendapat respons positif dari para guru. Hal ini dibuktikan dari hasil analisis kuesioner evaluasi pelatihan yang menunjukkan sebanyak 64\% peserta memberikan respons kategori yang sangat bermanfaat. Dengan demikian, Pelatihan Penelitian Tindakan Kelas ini dapat meningkatkan pengetahuan, motivasi dan keterampilan guru MTs Mizanul 'Ulum Sanrobone Kabupaten Takalar dalam menyusun Penelitian Tindakan Kelas.
\end{abstract}

Kata Kunci: Penelitian Tindakan Kelas, Guru 


\section{PENDAHULUAN}

Dalam pembelajaran di sekolah, seorang guru sudah dipastikan berhadapan dengan berbagai kegiatan, baik yang menyangkut peserta didik, materi ajar, metode pembelajaran, dan sebagainya. Guru harus terus berupaya meningkatkan kompetensi dan profesioanalismenya agar proses pembelajaran yang dilakukan di kelas dapat semakin bermutu. Untuk menjadi guru yang profesional, menurut Kunandar (2011), guru dituntut dengan sejumlah persyaratan, seperti memiliki kualifikasi pendidikan profesi yang memadai, memiliki kompetensi keilmuan sesuai dengan bidang yang ditekuni, memiliki kemampuan berkomunikasi yang baik dengan anak didik, mempunyai jiwa kreatif dan produktif, mempunyai etos kerja dan komitmen tinggi terhadap profesi, dan selalu melakukan pengembangan diri secara terus menerus melalui kegiatan penelitian, organisasi profesi, seminar, dan semacamnya.

Dalam Permen PAN-RB Nomor 16 Tahun 2009 tentang Jabatan Fungsional Guru dan Angka Kreditnya disebutkan bahwa untuk kenaikan pangkat jabatan fungsional guru serendah-rendahnya golongan III/b diwajibkan membuat karya inovatif berupa penelitian, karya tulis ilmiah, alat peraga, buku, atau karya teknologi pendidikan yang nilai angka kreditnya disesuaikan. Senada dengan hal tersebut, setiap guru menurut Mansyur \& Akidah (2018) dituntut untuk selalu belajar bagaimana menjadi guru yang profesional dan memiliki kompetensi yang mumpuni. Tidak hanya kompetensi dalam proses pembelajaran di kelas, tetapi juga kompetensi profesional dalam bidang penelitian, yang pada umumnya dalam bentuk Penelitian Tindakan Kelas. Lebih lanjut Mansyur (2013) menjelaskan bahwa guru secara terus menerus harus belajar sebagai upaya pembaharuan atas ilmu pengetahuan yang dimilikinya. Caranya dapat dilakukan dengan aktif melakukan penelitian maupun dalam kegiatan MGMP (Musyawarah Guru Mata Pelajaran). Untuk mewujudkan hal tersebut, guru harus dibekali dengan kemampuan meneliti, khususnya Penelitian Tindakan Kelas.

Penelitian Tindakan Kelas (PTK) merupakan bentuk penelitian tindakan yang diterapkan dalam aktivitas pembelajaran di kelas. Menurut Arikunto (2006), PTK adalah suatu bentuk penelitian reflektif yang dilakukan oleh pendidik sendiri terhadap kurikulum, pengembangan sekolah, meningkatkan prestasi belajar, pengembangan keahlian mengajar, dan sebagainya. Tindakan yang dilakukan dalam kelas merupakan bagian dari kegiatan penelitian dalam rangka memecahkan masalah di kelas. Tindakan tersebut dilakukan pada situasi alami, serta ditujukan untuk memecahkan masalah praktis. Dalam melaksanakan PTK, tujuan yang hendak dicapai oleh guru adalah untuk memperbaiki kualitas proses dan hasil pembelajaran yang pelaksanaannya dilakukan dalam beberapa siklus.

Adapun manfaat Penelitian Tindakan Kelas bagi guru antara lain: (1) guru memiliki kemampuan memperbaiki proses pembelajaran melalui suatu kajian yang mendalam terhadap apa yang terjadi di kelasnya; (2) guru dapat mengembangkan dan meningkatkan kinerjanya secara profesional karena guru mampu menilai, merefleksi diri, dan mampu memperbaiki pembelajaran yang dikelolanya; (3) guru mendapat kesempatan berperan aktif dalam mengembangkan pengetahuan dan keterampilan sendiri; dan (4) guru dapat merasa lebih percaya diri. 
Selain hal tersebut, manfaat Penelitian Tindakan Kelas juga menghasilkan laporan hasil penelitian yang dapat dikembangkan menjadi sebuah luaran berupa artikel ilmiah atau makalah yang dapat disajikan dalam forum ilmiah atau dipublikasikan pada jurnal ilmiah. Tentunya hal ini ikut mendukung profesionalisme dan karier guru, sebagaimana disebutkan dalam Permendiknas Nomor 35 Tahun 2010 tentang Petunjuk Teknis Pelaksanaan Jabatan Fungsional Guru, yang salah satu persyaratannya adalah melakukan penelitian tindakan kelas dan dipublikasikan (Utami \& Sutrisno, 2017).

Kemampuan guru dalam menyusun Penelitian Tindakan Kelas tentu tidak datang dengan sendirinya, tetapi melalui berbagai pelatihan dan pengalaman dalam meneliti. Bukan hal yang tidak mungkin seorang guru mampu menulis dan menguasi Penelitian Tindakan Kelas dengan baik. Pemahaman guru dalam melakukan Penelitian Tindakan Kelas secara mendalam akan turut mempengaruhi kualitas pembelajaran dan kredibiltas lembaga atau sekolah di mana guru tersebut mengabdikan diri. Tidak terkecuali di Madrasah Tsanawiyah (MTs) Mizanul 'Ulum Desa Sanrobone Kabupaten Takalar yang dijadikan sebagai mitra kegiatan pengabdian kepada masyarakat.

MTs Mizanul 'Ulum Sanrobone telah berdiri sejak 25 tahun silam, tepatnya pada tanggal 23 Juli 1993. Sekolah ini merupakan binaan Yayasan Wakaf Universitas Muslim Indonesia, Makassar (YW-UMI). Sekolah yang didirikan di atas tanah seluas 4125 M2 terletak di Dusun Bontowa, Desa Sannrobone, Kecamatan Sanrobone, Kabupaten Takalar, Provinsi Sulawesi Selatan, atau sekitar 41 KM dari Kota Makassar.

Hasil pengamatan yang sebelumnya telah dilakukan di MTs Mizanul 'Ulum Sanrobone, dapat dirumuskan bahwa permalahan mitra adalah masih banyaknya guru yang kurang memahami bentuk dan cara melakukan Penelitian Tindakan Kelas. Sebagian besar guru di sekolah tersebut masih menganggap bahwa Penelitian Tindakan Kelas terasa sulit dilakukan dan kadang dianggap sebagai pekerjaan sia-sia. Lebih dari itu, para guru pun belum mampu menjadikan kegiatan Penelitian Tindakan Kelas sebagai upaya untuk meningkatkan komptensi profesionalisme guru dan kualitas pembelajaran di sekolah.

Berdasarkan permasalahan mitra dan pemahaman dasar mengenai pentingnya Penelitian Tindakan Kelas bagi guru, maka dianggap perlu memberikan sebuah pelatihan kepada guru-guru MTs Mizanul 'Ulum Sanrobone Kabupaten Takalar dalam bentuk Pelatihan Penelitian Tindakan Kelas.

\section{METODE PELAKSANAAN}

Kegiatan Pengabdian kepada Masyarakat (PKM) ini dilaksanakan di MTs Mizanul 'Ulum Desa Sanrobone Kabupaten Takalar. Metode yang digunakan dalam kegiatan ini adalah metode pelatihan. Peserta yang menjadi sasaran atau mitra sasar kegiatan Pelatihan Penelitian Tindakan Kelas ini adalah keseluruhan guru MTs Mizanul 'Ulum Sanrobone, yakni sebanyak 25 guru. Dalam pelaksanaannya, kegiatan pelatihan melibatkan beberapa mahasiswa Program Studi Pendidikan Bahasa dan Sastra Indonesia UMI, yakni sebanyak 3 orang.

Pelatihan Penelitian Tidakan Kelas ini dilaksanakan dalam tiga tahapan, yakni (1) tahap persiapan, (2) tahap pelaksanaan, dan (3) tahap evaluasi. Pada tahap persiapan 
dilakukan beberapa kegiatan, antara lain: melakukan observasi ke lokasi mitra pengabdian, mengurus persuratan perizinan dan persetujuan antarlembaga pelaksana dan mitra sasar, mempersiapkan tempat pelatihan, alat dan bahan pelatihan, serta menyusun jadwal dan materi pelatihan. Selanjutnya, pada tahap pelaksanaan dilakukan kegiatan antara lain: registrasi peserta pelatihan, acara pembukaan pelatihan, dan pelaksanaan Pelatihan Penelitian Tindakan Kelas. Dan, pada tahap evaluasi, dilakukan evaluasi berupa penyebaran kuesioner untuk mengukur sejauh mana kebermanfaatan kegiatan pelatihan yang telah dilaksanakan kepada guru MTs Mizanul 'Ulum Sanrobone Kabupaten Takalar.

\section{HASIL DAN PEMBAHASAN}

Pengabdian kepada Masyarakat (PKM) berupa Pelatihan Penelitian Tindakan Kelas (PTK) diberikan kepada masyarakat mitra dengan tujuan meningkatkan pengetahuan dan keterampilan para guru MTs Mizanul 'Ulum Desa Sanrobone Kabupaten Takalar dalam menyusun PTK. MTs Mizanul 'Ulum Sanrobone Kabupaten Takalar berada di lokasi desa binaan Universitas Muslim Indonesia (UMI). Pelaksanaan Pelatihan Penelitian Tindakan Kelas dilaksanakan pada 2 Februari 2019 dan berlangsung di Aula Pertemuan MTs Mizanul 'Ulum Sanrobone.

Dalam pelaksanaan pelatihan, pemateri menyajikan beberapa materi yang memberikan pemahaman dan keterampilan kepada guru-guru mengenai prinsip dasar, karakteristik, langkah-langkah, dan sistematika Penelitian Tindakan Kelas. Adapun pemateri dalam pelatihan ini adalah (1) Umar Mansyur, S.Pd., M.Pd., Dosen Pendidikan Bahasa dan Sastra Indonesia, Universitas Muslim Iindonesia dan (2) Rahmat, S.S., M.Pd., Dosen Pendidikan Bahasa dan Sastra Indonesia, Universitas Muslim Iindonesia.

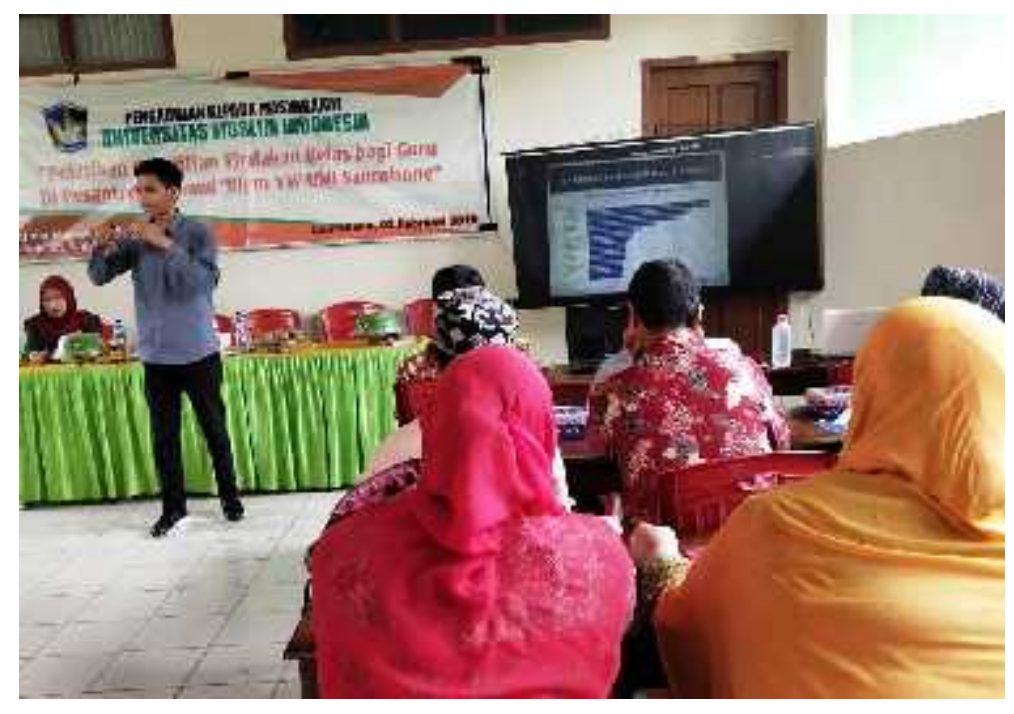

Gambar 1. Pemaparan Materi PTK oleh Umar Mansyur, S.Pd., M.Pd.

Pelatihan Penelitian Tindakan Kelas yang diberikan kepada guru MTs Mizanul 'Ulum Sanrobone Kabupaten Takalar mendapat respons yang sangat positif dari para peserta. Sebagian besar dari peserta selama ini rupanya merasa masih bingung dan kesulitan menyusun sebuah Penelitian Tindakan Kelas. Sehingga para guru justru 
berharap ada tindak lanjut setelah pelatihan dilaksanakan, yakni berupa pendampingan kepada guru MTs Mizanul 'Ulum Sanrobone Kabupaten Takalar dalam penyusunan laporan Penelitian Tindak Kelas, serta cara membuat artikel hasil penelitian yang dapat dipublikasikan pada jurnal ilmiah atau dipresentasikan pada forum ilmiah atau seminar.

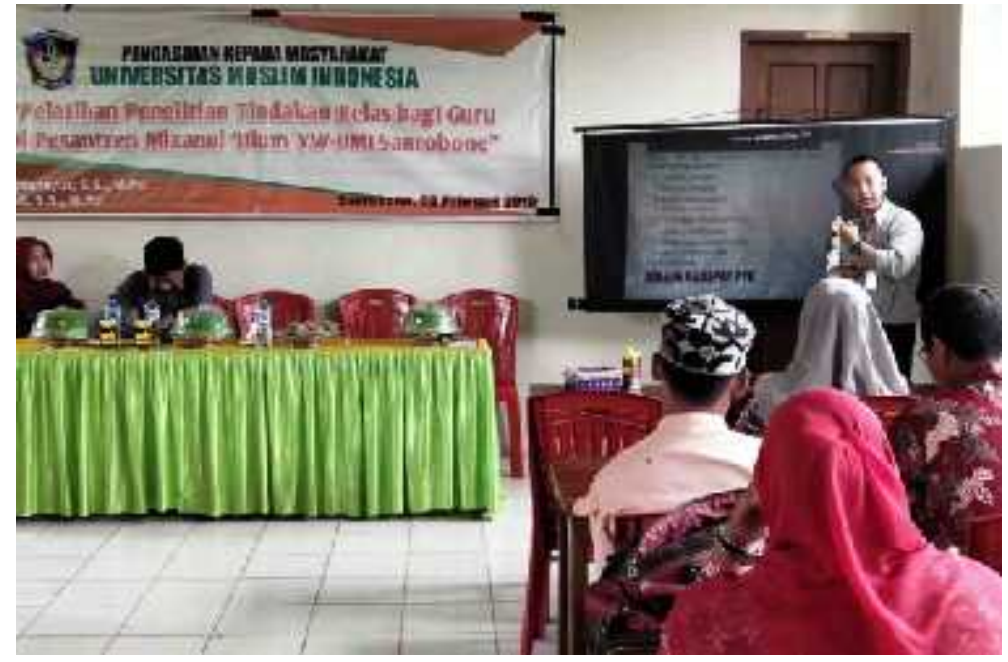

Gambar 2. Pemaparan Materi PTK oleh Rahmat, S.S., M.Pd.

Selanjutnya, jumlah guru yang ditargetkan mengikuti peserta pelatihan adalah sebanyak 25 guru. Dan, pada saat kegiatan berlangsung peserta yang hadir juga sebanyak 25 guru. Dengan demikian, secara persentase dapat dikatakan bahwa peserta yang hadir mengikuti kegiatan Pelatihan Penelitian Tindakan Kelas terpenuhi secara maksimal atau 100\% hadir. Ketercapaian target dari jumlah peserta yang direncanakan tidak terlepas dari komunikasi yang dibangun sejak awal oleh tim pelaksana PKM dengan Kepala MTs Mizanul 'Ulum Sanrobone Kabupaten Takalar dalam menentukan waktu dan format pelaksanaan kegiatan, sehingga kegiatan dapat berjalan dengan efektif dan efisien.

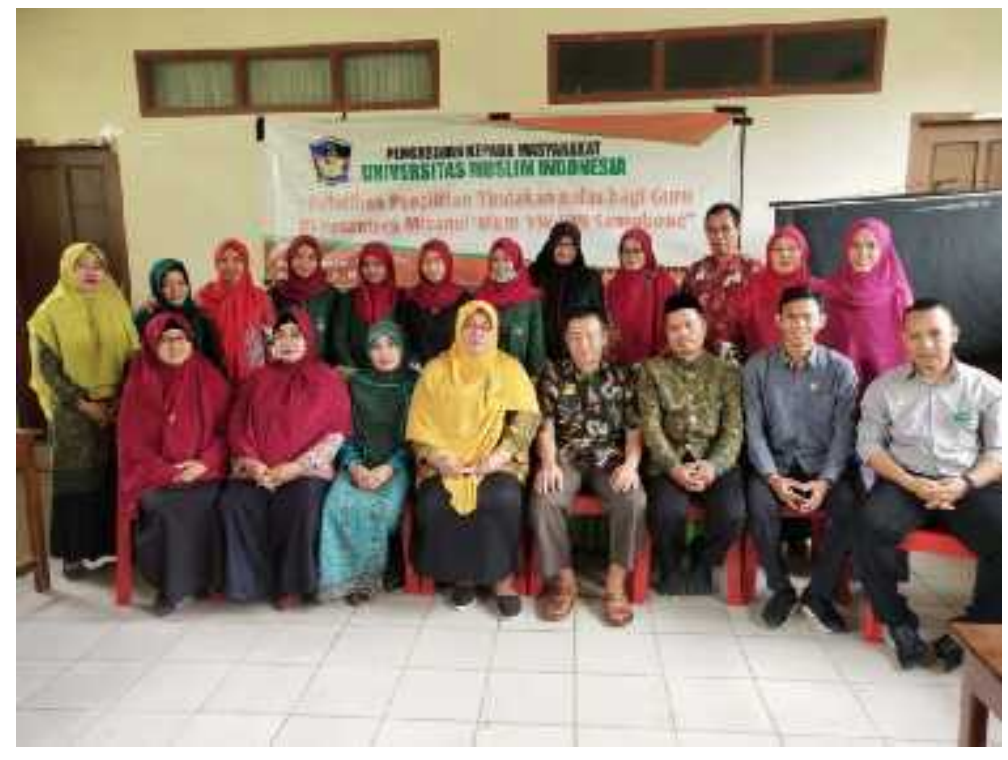

Gambar 3. Foto Bersama Pemateri dengan Peserta Pelatihan PTK 
Untuk mengukur tingkat pemahaman guru setelah mengikuti pelatihan, maka dilakukan evaluasi dalam bentuk penyebaran kuesioner. Kuesioner diberikan kepada guru MTs Mizanul 'Ulum Sanrobone Kabupaten Takalar untuk mengukur tingkat pemahaman peserta dan respons mengenai kebermanfaatan kegiatan pelatihan yang telah mereka ikuti. Hasil tabulasi data skor kuesioner (skor maksimal 54) yang telah diperoleh kemudian diklasifikasi ke dalam empat kategori respons, yakni sangat bermanfaat (SB), bermanfaat (B), kurang bermanfaat (KB), dan tidak bermanfaat (TB). Secara rinci, hasil analisis kuesioner dapat dilihat pada tabel berikut.

Tabel 1. Tingkat Respons Peserta Pelatihan Penelitian Tindakan Kelas

\begin{tabular}{ccccc}
\hline No. & Kategorisasi & Interval Nilai & Frekuensi & Persentase (\%) \\
\hline 1. & Sangat Bermanfaat & $46-54$ & 16 & 64 \\
2. & Bermanfaat & $36-45$ & 9 & 36 \\
3. & Kurang Bermanfaat & $20-35$ & 0 & 0 \\
4. & Tidak Bermanfaat & $0-19$ & 0 & 0 \\
\hline & Jumlah & 25 & 100 \\
\hline
\end{tabular}

Berdasarkan Tabel 1 diketahui respons peserta pelatihan menunjukkan bahwa dari keseluruhan peserta yang telah mengikuti kegiatan pelatihan, terdapat 16 peserta atau sebanyak 64\% memberikan respons kategori sangat bermanfaat, dan 9 peserta lainnya atau sebanyak 36\% memberikan respons kategori bermanfaat. Hasil ini selaras dengan fakta yang tampak selama kegiatan pelatihan berlangsung, para peserta sangat bersemangat memperhatikan materi yang disajikan. Selain itu, pada sesi tanya-jawab, peserta juga antusias memberikan pertanyaan dan tanggapan kepada pemateri. Mayoritas peserta menganggap kegiatan pelatihan yang diberikan telah mampu meningkatkan motivasi, pengetahuan dan keterampilan mereka dalam menyusun Penelitian Tindakan Kelas.

\section{SIMPULAN}

Berdasarkan hasil pelaksanaan Pelatihan Penelitian Tindakan Kelas bagi Guru MTs Mizanul 'Ulum Sanrobone Kabupaten Takalar dapat disimpulkan bahwa kegiatan pengabdian kepada masyarakat tersebut terlaksana dengan baik dan lancar. Pelatihan yang telah dilaksanakan juga menghasilkan Pedoman Penelitian Tindakan Kelas yang dapat dijadikan sebagai panduan dan format bagi para guru dalam menyusun Penelitian Tindakan Kelas. Selain itu, pelaksanaan pelatihan mendapat respons yang positif dari para guru MTs Mizanul 'Ulum Sanrobone Kabupaten Takalar. Hal ini dibuktikan dari hasil analisis kuesioner evaluasi pelaksanaan pelatihan yang menunjukkan sebanyak 64\% peserta memberikan respons kategori yang sangat bermanfaat. Dengan demikian, Pelatihan Penelitian Tindakan Kelas ini dapat meningkatkan motivasi, pengetahuan dan keterampilan guru MTs Mizanul 'Ulum Sanrobone Kabupaten Takalar dalam menyusun Penelitian Tindakan Kelas. 


\section{DAFTAR RUJUKAN}

Arikunto, S. dkk. (2006). Penelitian Tindakan Kelas. Jakarta: Bumi Aksara.

Kunandar. (2011). Guru Profesional: Implementasi Kurikulum Tingkat Satuan Pendidikan (KTSP) dan Sukses dalam Sertifikasi Guru. Jakarta: Rajawali Pers.

Mansyur, U. \& Akidah, I. (2018). Peningkatan Kompetensi Profesional Guru MTs DDI Padanglampe Kabupaten Pangkep melalui Pelatihan Penulisan Karya Tulis Ilmiah. JPPM: Jurnal Pengabdian dan Pemberdayaan Masyarakat, 2(2), 273-278.

Mansyur, U. (2013). Evaluasi Kompetensi Pedagogik Guru Bahasa Indonesia SMP Peserta MGMP dan yang Bukan Peserta MGMP di Kabupaten Pinrang. Tesis. Makassar: Universitas Negeri Makassar.

Peraturan Menteri PAN-RB Nomor 16 Tahun 2009 tentang Jabatan Fungsional dan Angka Kreditnya.

Utami, P.S. \& Sutrisno. (2017). Pelatihan Teknik Penulisan Penelitian Tindakan Kelas pada Guru PPKn MTs di Kabupaten Ponorogo. J-ABDIPAMAS (Jurnal Pengabdian Kepada Masyarakat), 1(1), 81-91. 
54 J-Abdipamas, Vol. 3, No. 2 Oktober, 2019 